\title{
Eighty-ninth Annual Report of The American Phytopathological Society
}

\section{REPORT OF THE TREASURER}

The Financial Advisory Committee and APS headquarters' staff members met on 28 February and 2 and 3 June in St. Paul, MN, and on 8 August 1997 in Rochester, NY, to review financial matters related to the operation of the Society and to prepare the budget for FY98. The approved minutes of the March and June meetings were distributed to the division councilors and are on file at APS headquarters. The minutes of the August meeting have not been distributed, but the most significant agenda items of these three meetings are summarized in this report.

1) The reserves of the Society have developed under the leadership of Dr. Stan Pennypacker, treasurer of the Society for the previous 6 years. To assure that the reserves are managed for the best benefit of the Society, the services of First Bank of Minneapolis, MN, have been obtained. In July 1997, \$500,000 were transferred from the operating reserve to an account at First Bank for management with the investment objectives of obtaining both growth and income from these funds to serve the future needs of our Society.

2) A simplified accounting report was developed that provides committee members the necessary information, in a succint fash- ion, on income and expenses of member services, the journals, Phytopathology News, APS Press, and the Annual Meeting. This information is presented in Table 1.

3) The Financial Advisory Committee recommended that support for the APS Foundation and the National Plant Pathology Board be increased by $\$ 4,000$ and $\$ 5,000$, respectively. In addition, the Financial Advisory Committee recommended that a total

TABLE 2. Comparison of The American Phytopathological Society fiscal years 1988 to 1997 before reserve allocation

\begin{tabular}{lccc}
\hline Fiscal year & Income & Expenses & Surplus (deficit) \\
\hline FY97 & $\$ 3,418,515$ & $\$ 3,216,584$ & $\$ 201,931$ \\
FY96 & $\$ 3,198,990$ & $\$ 2,974,105$ & $\$ 224,885$ \\
FY95 & $\$ 3,152,468$ & $\$ 2,907,285$ & $\$ 245,183$ \\
FY94 & $\$ 3,062,160$ & $\$ 2,902,793$ & $\$ 159,367$ \\
FY93 & $\$ 2,843,296$ & $\$ 2,574,006$ & $\$ 269,290$ \\
FY92 & $\$ 2,689,171$ & $\$ 2,565,571$ & $\$ 123,600$ \\
FY91 & $\$ 2,436,386$ & $\$ 2,471,744$ & $(\$ 35,358)$ \\
FY90 & $\$ 2,260,693$ & $\$ 2,258,159$ & $\$ 2,534$ \\
FY89 & $\$ 2,213,691$ & $\$ 2,177,068$ & $\$ 36,623$ \\
FY88 & $\$ 1,903,918$ & $\$ 1,897,972$ & $\$ 5,946$ \\
\hline
\end{tabular}

TABLE 1. Unaudited summary of income and expenses as related to function of The American Phytopathological Society

\begin{tabular}{|c|c|c|c|c|c|c|c|c|c|}
\hline \multirow[b]{2}{*}{ Function } & \multicolumn{4}{|c|}{ Income } & \multicolumn{4}{|c|}{ Expenses } & \multirow{2}{*}{$\begin{array}{c}\text { Y-T-D } \\
\text { profit (loss) }\end{array}$} \\
\hline & Actual & $\%$ & Budget & $\%$ & Actual & $\%$ & Budget & $\%$ & \\
\hline Member services & $\$ 338,719$ & 9.91 & $\$ 373,525$ & 11.43 & $\$ 646,918$ & 20.10 & $\$ 659,451$ & 20.05 & $(\$ 308,199)$ \\
\hline Phytopathology & $\$ 655,064$ & 19.16 & $\$ 643,120$ & 19.68 & $\$ 413,976$ & 12.87 & $\$ 469,408$ & 14.27 & $\$ 241,088$ \\
\hline Phytopathology News & $\$ 16,404$ & 0.48 & $\$ 17,200$ & 0.53 & $\$ 82,212$ & 2.56 & $\$ 70,681$ & 2.15 & $(\$ 65,808)$ \\
\hline MPMI & $\$ 284,121$ & 8.31 & $\$ 226,285$ & 6.93 & $\$ 247,919$ & 7.71 & $\$ 277,064$ & 8.42 & $\$ 36,202$ \\
\hline APS Press & $\$ 1,163,116$ & 34.02 & $\$ 1,079,607$ & 33.04 & $\$ 1,087,732$ & 33.82 & $\$ 1,009,263$ & 30.68 & $\$ 75,384$ \\
\hline Total & $\$ 3,418,515$ & 100.00 & $\$ 3,267,611$ & 100.00 & $\$ 3,216,584$ & 100.00 & $\$ 3,289,737$ & 100.00 & \\
\hline Operating surplus (loss) & & & & & & & & & $\$ 201,931$ \\
\hline
\end{tabular}

${ }^{a} \mathrm{G} \& \mathrm{~A}$ is assigned to functions based on payroll dollars.

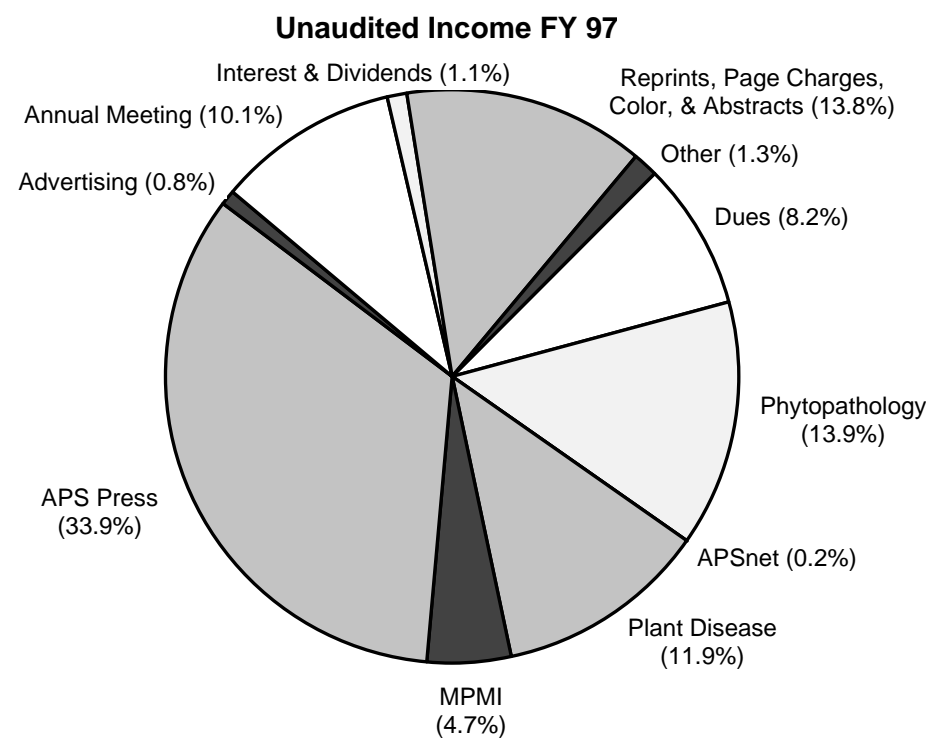

\section{Unaudited Expenses FY 97}

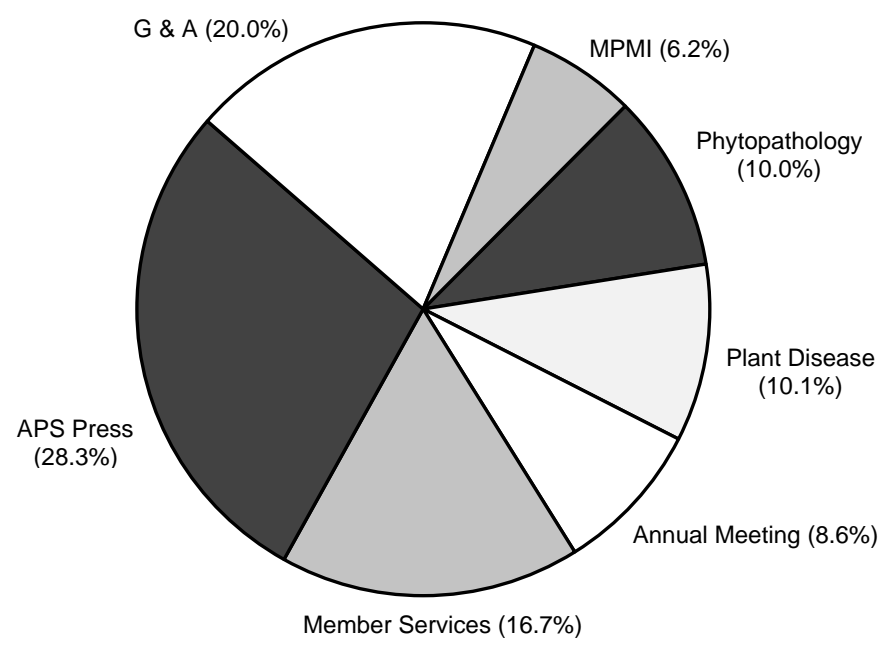


of $\$ 1,000$ be provided for the Diversity Committee over the next 2 years.

I am pleased to report that our Society completed FY97 with an unaudited balanced budget of $\$ 201,931$ after allocating to our reserves, capital improvement expenses, and cash assets. Our total income $(\$ 3,418,515)$ was derived from eleven sources (unaudited income FY 97), and our total operating expenses $(\$ 3,216,584)$ incurred during FY97 are partitioned into seven categories (unaudited expenses FY 97). After allocating \$26,771 for maintenance reserves and capital improvement expenses, our operating surplus totaled
$\$ 175,656$ compared with our FY97 budget that was approved with a net loss of $\$ 48,896$. The favorable surplus resulted from reduced total operating expenses and increased revenues from what was budgeted in June 1996. The income and expenses of the Society for the most recent $10 \mathrm{FYs}$, before reserve allocation, are presented in Table 2.

The total assests as of 30 June 1997, excluding restricted funds, were $\$ 3,163,157$ and current liabilities totaled $\$ 2,193,429$, producing a membership equity of $\$ 969,728$.

The audited financial statement for FY97 appears in this issue of Phytopathology.

\section{REPORT OF THE AUDITOR}

The American Phytopathological Society has its accounts audited annually be a certified public accountant. In recent years the accounting firm has been Phillips and Swanson, St. Paul, MN. Due to recent changes in reporting requirements by the American Institute of Certified Public Accountants for nonprofit organizations, the full audit has become extensive and has undergone changes in format. Consequently, only the Balance Sheet and Income and Expense Statement as of June 30, 1997, are being published in detail. Any member wishing a copy of the full audit may obtain one on request.

The American Phytopathological Society Balance Sheet Year ended June 30, 1997 (with comparative totals for 1996)

\begin{tabular}{|c|c|c|c|c|}
\hline & & 1997 & & 1996 \\
\hline \multicolumn{5}{|l|}{ Assets } \\
\hline Cash (note $\left.3^{a}\right)$ & $\$$ & $1,481,855$ & $\$$ & $1,377,908$ \\
\hline Interest receivable & & 4,318 & & 5,822 \\
\hline Accounts receivable, net (note 17 ) & & 140,658 & & 128,099 \\
\hline Investments (note 4) & & 332,289 & & 401,895 \\
\hline Prepaid expenses (note 5) & & 140,648 & & 201,623 \\
\hline Inventory & & 624,702 & & 481,232 \\
\hline Loan receivable & & & & 19,500 \\
\hline Prepaid pension (note 14) & & 29,340 & & 27,651 \\
\hline Property and equipment, net (note 6) & & 517,178 & & 541,383 \\
\hline Total assets & $\$$ & $3,270,988$ & $\$$ & $3,185,113$ \\
\hline
\end{tabular}

Liabilities and net assets

Liabilities

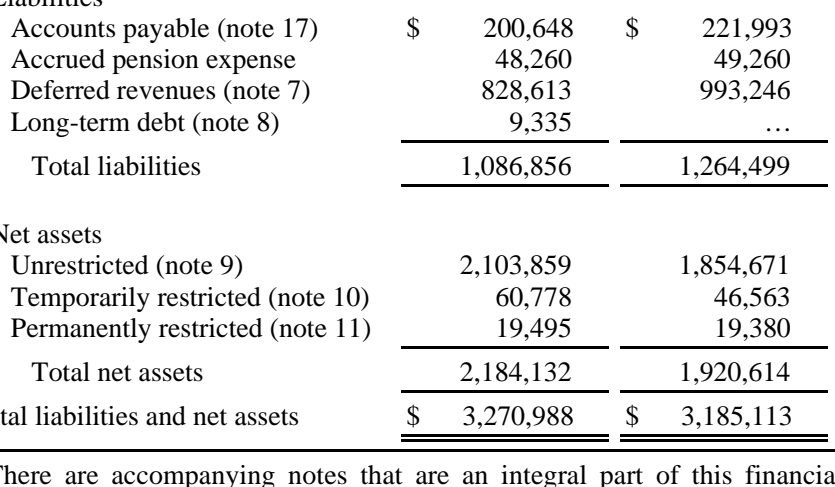

a There are accompanying notes that are an integral part of this financial statement and are available upon request.
The American Phytopathological Society

Statement of Changes in Net Assets

Year ended June 30, 1997 (with comparative totals for 1996)

\begin{tabular}{|c|c|c|}
\hline & 1997 & 1996 \\
\hline \multicolumn{3}{|l|}{ Unrestricted net assets } \\
\hline \multicolumn{3}{|l|}{ Revenue } \\
\hline Membership dues & $\$ 301,394$ & $\$ 477,215$ \\
\hline Subscriptions & $1,023,629$ & 843,500 \\
\hline Reprints & 93,675 & 83,537 \\
\hline Abstracts & 29,545 & 26,310 \\
\hline Page charges & 214,367 & 200,579 \\
\hline Processing fees & 68,400 & 40,850 \\
\hline Back issues & 21,330 & 25,216 \\
\hline Color charges & 64,521 & 44,210 \\
\hline Advertising & 28,031 & 32,025 \\
\hline Books and slides & $1,159,161$ & $1,052,320$ \\
\hline Annual reviews & 6,685 & 6,719 \\
\hline Annual meeting & 346,364 & 314,026 \\
\hline Investment income (note 4) & 79,591 & 76,364 \\
\hline Loss on sale of equipment & $(523)$ & \\
\hline Loss on sale of investments (note 4) & $(1,392)$ & $(1,577)$ \\
\hline Unrealized gain on investments (note 4 ) & 1,447 & 2,458 \\
\hline Other & 23,391 & 16,934 \\
\hline Total revenue & $3,459,616$ & $3,240,686$ \\
\hline \multicolumn{3}{|l|}{ Net assets released from restrictions } \\
\hline Restrictions satisfied by payments & 31,140 & 29,492 \\
\hline \multicolumn{3}{|l|}{ Expenses } \\
\hline \multicolumn{3}{|l|}{ Program services } \\
\hline Member services & 503,317 & 502,375 \\
\hline Journals & 916,237 & 915,268 \\
\hline Books & 908,321 & 747,191 \\
\hline Annual meeting & 276,791 & 260,778 \\
\hline Total program services & $2,604,666$ & $2,425,612$ \\
\hline \multicolumn{3}{|l|}{ Supporting services } \\
\hline Management and general & 636,902 & 576,732 \\
\hline Total expenses & $3,241,568$ & $3,002,344$ \\
\hline Increase in unrestricted net assets & 249,188 & 267,834 \\
\hline \multicolumn{3}{|l|}{ Temporarily restricted net assets } \\
\hline Support for books & 10,226 & 6,250 \\
\hline Support for annual meeting socials & 17,050 & 14,450 \\
\hline Support for virus list & 16,500 & 4,000 \\
\hline Investment income (note 4) & 1,579 & 1,232 \\
\hline Restrictions satisfied by payments & $(31,140)$ & $(29,492)$ \\
\hline $\begin{array}{l}\text { Increase (decrease) in temporarily } \\
\text { restricted net assets }\end{array}$ & 14,215 & $(3,560)$ \\
\hline \multicolumn{3}{|l|}{ Permanently restricted net assets } \\
\hline $\begin{array}{l}\text { Unrealized gain (loss) on investments } \\
\text { (note 4) }\end{array}$ & 115 & (378) \\
\hline Increase in net assets & 263,518 & 263,896 \\
\hline Net assets, beginning of year & $1,920,614$ & $1,656,718$ \\
\hline Net assets, end of year & $\$ 2,184,132$ & $\$ 1,920,614$ \\
\hline
\end{tabular}

a There are accompanying notes that are an integral part of this financial statement and are available upon request. 